\title{
ESL STUDENT TEACHERS' BELIEFS ABOUT LEARNING ARABIC AS A FOREIGN LANGUAGE
}

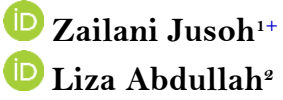

\author{
${ }^{'}$ Faculty of Languages and Communication, Universiti Sultan Zainal \\ Abidin, Malaysia. \\ Email:zailani@unisza.edu.my \\ ${ }^{2}$ International Islamic University Malaysia, Kuala Lumpur, Malaysia. \\ Email:liza_abdullah@izum.edu.my
}

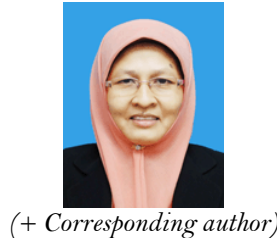

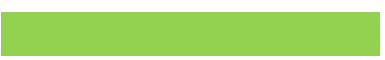

Article History

Received: 11 October 2019 Revised: 13 November 2019 Accepted: 18 December 2019 Published: 7 January 2020

Keywords

Arabic language BALLI

Descriptive

English as a second language

Foreign language

Language beliefs

Student teachers.

\section{ABSTRACT}

Learning a foreign language is a daunting task for many especially adult learners. This is because their motivation to learn the languages varies from one individual to another. Some do it to fulfill graduation requirement from the institution they are studying in while others, for fun. Thus, owing to these differences, understanding their attitude and beliefs about the language they take up is important as the belief affects language learning performance. This paper is written to investigate the beliefs of student teachers majoring in Teaching English as a Second Language (TESL) about learning Arabic as a foreign/third language. The respondents were enrolled in Arabic as foreign language class to meet the graduation requirement. Data for the study were collected using BALLI, an instrument to measure students' beliefs about language learning. As this is a descriptive study, the data gathered were analysed using percentage. In general, respondents held positive beliefs about learning Arabic despite having some unrealistic beliefs about the language. The findings have a number of contributions both pedagogically and practically. One pedagogical implication the study contributes is with regards to the needs to inculcate realistic beliefs among students in learning Arabic as a foreign language.

Contribution/ Originality: This study is one of very few studies which have investigated beliefs about learning Arabic among students training to be ESL teachers. What makes the study different is the fact that the respondents have no prior formal instruction in Arabic but are already familiar with Arabic through daily religious rituals and through native language which contains numerous Arabic loan words.

\section{INTRODUCTION}

In this borderless world, the ability to speak in more than one language is highly valued for a number of practical purposes including employment, travel, and education. Presently, although English is still the most popular second language, being spoken by more than 1.5 billion people worldwide of which 1.1 billion are nonnative English speakers (www.statistica.com), other languages such as Mandarin, Japanese and Arabic are gaining popularity among language learners. This is because the learners see great potentials in learning those languages in terms of material benefits gained from knowing the languages. This has led to an increasing interest in learning these languages. 


\subsection{Language Education in Malaysia}

Malaysia is a plural society comprising people from diverse ethnic backgrounds. The three main ethnics are Malays, Chinese, and Indians, in addition to scores of other minority groups. Each of these ethnics speaks their own language such as Bahasa Malaysia, Tamil, Mandarin, and others. Owing to its diversity, Bahasa Malaysia has been the official language of the country since independence to unite its citizens.

Nonetheless, English is also given a special status due to its historical, economic and diplomatic importance. Because of this, learning English as a second language is made compulsory for all students at all levels of education, from primary to tertiary. Not only is English taught as a second language, it is also used as a medium for teaching subjects such as Mathematics and Science in school through various policies such as the teaching of mathematics and science in English (EtEMS) and dual language programme (DLP). These show that the government places great importance on having citizens with good proficiency in English.

However, as the country is forging ahead with its aim of becoming a developed nation and at the same time is trying to remain competitive in terms of trade and commerce, the government has taken several initiatives to ensure that the aims materialize. One of the initiatives is by empowering its human capitals through the implementation of the National Education Blueprint 2013 -2025 (Ministry of Higher Education Malaysia, 2007) which urges more Malaysian students to take up other foreign languages to stay competitive when they enter the workforce. It states that:

The aspiration of the education system is to create students that are at least operationally proficient in both Bahasa Malaysia and English. All students will also be encouraged to learn an additional language to independent proficiency. It is hoped that by 2025 , at least $30 \%$ students achieve independent proficiency in an additional language (MOE, 2007).

The seriousness of the government in encouraging its citizens to learn other foreign languages has led to the opening of foreign language classes at higher education institutions throughout the country. In fact, in some universities, language class is a requirement for graduation. One of the foreign languages commonly offered in Malaysian public universities is Arabic. Indeed Arabic is offered by all public universities in Malaysia. A number of universities (seven out of 20) also offer programmes in teaching of Arabic at all levels from degree to doctoral programmes (Ibrahim and Rahman, 2018).

Although Arabic is considered a foreign language in Malaysia, it is not alien to Malaysians due to a number of reasons. First of all, Arabic is the main language for those who profess Islam, who make up $61.3 \%$ of the population of Malaysia (Department of Statistics Malaysia, 2019) to perform religious duties (Meshkat and Saeb, 2014). Secondly, the influence of Arabic on the official language of the country, Bahasa Malaysia (BM) is huge as a significant number of words in BM are borrowed from Arabic. The loan words are not only related to religious matters but also other areas including scientific, intellectual, and legal. (Beg 1979 as cited in Ibrahim and Rahman (2018)). Thus many Malaysians are familiar with Arabic words. Furthermore, Arabic is also taught in religious schools as an additional (third) language and it has even been offered as an elective subject even in primary school since the introduction of KSSR in 2011

Despite the familiarity with the language, and constant exposure to Arabic among Malay Muslims in Malaysia, for many, it is still regarded as a very challenging and difficult language to learn (Rosni et al., 2016). Part of the reason lies in the students' passive attitude towards the language (Rosni, 2013 as cited in (Rosni et al., 2016)). In order to understand other reason/s behind this difficulty, it is important to explore the kind of beliefs students have with regard to learning the language. According to Marzano (1992) attitudes and perceptions are important as "without positive attitudes and perceptions, students have little chance of learning proficiently, if at all”. Although his statement was made in reference to attitudes in learning in general, the same concept applies to language learning. In fact in language learning similar statement was reiterated. Gardner (1985) stresses on the need to have positive attitudes towards foreign language learning as this would contribute to the language learning process 
significantly. Having the right attitudes towards language learning is important because of the influence the attitudes has on language performance. Understanding students' perspectives on language learning helps practitioners create a more conducive environment and helps students become more motivated and successful in learning. Interests in the roles of beliefs and attitudes in learning languages have grown tremendously over the past few decades. Nonetheless, a large majority of the studies were conducted among languages such as English, Mandarin, Japanese or Arabic (Altan, 2006; Ariogul et al., 2009) in second language contexts. Very few have investigated the beliefs about learning Arabic as a foreign or a third language.

\subsection{Related Studies on Beliefs about Arabic Language}

Interests in learning Arabic have enormously risen in many parts of the world. This spike in interest has become obvious after September 11, 2001 tragedy. In the US, the Modern Language Association, reported that demands for Arabic courses has increased by three folds (Goldberg et al., 2015). Presently, Heldt (2014) discovered that Arabic has become one of the fastest-growing foreign languages in the U.S. and it is the 10th most-studied language in the United States.

As mentioned previously, learner beliefs about language learning have huge impact, both positively or negatively on their overall language performance. Because of this, several studies investigating attitude and beliefs among learners of Arabic have been conducted although the number is rather limited. One such study was by Kuntz (1996). She studied the beliefs of university students learning Arabic in the US. The finding indicates that the students of Arabic showed unique beliefs with regard to language learning as they prefer statements related to communication strategies and the people of the language. Similarly, Meshkat and Saeb (2014) compared the beliefs held by Iranian high school students in learning English and Arabic. The beliefs differ significantly in four of the five categories indicating that students have more positive beliefs towards English rather than Arabic because of the social status associated with English.

Although beliefs are influenced by the context of learning, not much has been done to investigate the issue in Malaysian context. The study conducted by Yusri et al. (2012) found that learning environment has a great influence on the attitude of students as well as the learning process. Thus it would be interesting to investigate whether the students taking the Arabic language hold positive or negative perceptions towards the language.

\subsection{Objective of the Study}

The main objective of the study was to investigate the beliefs TESL students hold about learning Arabic as a third language.

\section{METHOD}

The following section describes the methodology employed in this study.

\subsection{Instrumentation}

An instrument, known as Beliefs about Language Learning Inventory (Horwitz, 1987) was the primary instrument used in data collection. BALLI was developed to measure the beliefs of students when learning foreign languages. The instrument is made up of 34 items, which were mostly rated on a five point Likert scale from strongly disagree (1) to strongly agree (5). The only exceptions were items 4 and 15 as the rating was slightly different. The instrument is divided into five components; namely language aptitude (9 items), the language learning difficulty ( 5 items), learning and communicating strategies ( 7 items), the nature of language learning (6 items) and motivation and expectations (6 items). 


\subsection{Data Analysis}

Data from the study were analysed descriptively using percentage. Before the analysis was performed, the responses were collapsed into 3 categories (disagree, neutral, agree) from the original scales of 5 for ease of discussion.

\subsection{Sample}

Students enrolling in diploma in TESL programme at a higher education institution in the east coast of peninsular Malaysia participated in the study. At the time of the data collection, 79 students were enrolled in compulsory foreign language classes such as Japanese, Arabic and Thai. However, only 17 students took up Arabic. Of the 17 students, the majority ( $88 \%$ ) were female students while male made up only $12 \%$.

\section{RESULTS}

The subsequent section presents the findings for the research question the study was interested in investigating.

\subsection{Beliefs about Learning Arabic}

Descriptive analysis using percentage was calculated to determine students' overall beliefs in Arabic language. The results are presented based on individual belief component.

Table-1. Students' beliefs based on language aptitude (in \%).

\begin{tabular}{|c|c|c|c|c|}
\hline No & Statement & Disagree & Neutral & Agree \\
\hline 1. & It is easier for children than adults to learn a foreign language. & 0 & 12 & 88 \\
\hline 2. & Some people have a special ability for learning foreign languages. & 6 & 24 & 71 \\
\hline 6. & Malaysians are good at learning foreign languages. & 6 & 59 & 25 \\
\hline 10. & $\begin{array}{l}\text { It is easier for someone who already speaks a foreign language to } \\
\text { learn another one. }\end{array}$ & 24 & 35 & 41 \\
\hline 11. & $\begin{array}{l}\text { People who are good at mathematics or science are not good at } \\
\text { learning foreign languages }\end{array}$ & $\mathrm{O}$ & 47 & 53 \\
\hline 16. & I have a special ability for learning foreign languages. & 53 & 30 & 18 \\
\hline 19. & Women are better than men at learning foreign languages. & 29 & 59 & 12 \\
\hline 30. & People who speak more than one language are very intelligent. & O & 12 & 88 \\
\hline 33. & Everyone can learn to speak a foreign language. & $\mathrm{O}$ & $\mathrm{O}$ & 100 \\
\hline
\end{tabular}

The first component of the instrument is language aptitude beliefs which measures students' belief regarding specific abilities for foreign language learning. The results for the component are presented in Table 1 . The respondents unanimously agree $(100 \%)$ with statement 33 regarding the belief that everyone has the ability to speak foreign language. A rather big proportion of respondents (88\%) agree that it is easier for children than adults to learn a foreign language and people who speak more than one language are very intelligent.

Table-2. Students' beliefs based on language learning motivation and expectation (in \%).

\begin{tabular}{l|l|c|c|c}
\hline No & Statement & Disagree & Neutral & Agree \\
\hline 5. & I believe that I will learn to speak Arabic very well. & 12 & 47 & 41 \\
\hline 20. & Malaysians feel that it is important to speak Arabic. & 59 & 41 & 0 \\
\hline 24. & $\begin{array}{l}\text { I would like to learn Arabic so that I can get to know } \\
\text { native speakers better and their cultures. }\end{array}$ & 18 & 18 & 64 \\
\hline 29. & $\begin{array}{l}\text { If I learn Arabic very well, I will have better } \\
\text { opportunities for a good job. }\end{array}$ & 6 & 41 & 53 \\
\hline 31. & I want to learn to speak Arabic well. & 0 & 0 & 100 \\
\hline 32. & $\begin{array}{l}\text { I would like to have friends who speak Arabic as a } \\
\text { native language. }\end{array}$ & 12 & 82 \\
\hline Source: Horwitz (1987).
\end{tabular}


Similarly, $71 \%$ of the respondents believe that Some people have a special ability for learning foreign languages. Conversely, a big percentage (53\%) disagree to similar statement regarding their own ability to learn foreign languages. This shows that students do not have the confidence in their own ability to learn although they believe that everyone else has the ability to do that. However, this response could be viewed from cultural perspectives. Eastern culture practiced by the Malaysians prevents the students from boasting about their own ability.

Table 2 presents the results for the beliefs about language learning motivation and expectation. Most items in this category were rated positively. Item 32 I want to learn to speak Arabic well was unanimously agreed while those related to having friends and knowing their cultures were also highly endorsed at $82 \%$ and $64 \%$ respectively. This shows that students were both intrinsically and extrinsically motivated to learn Arabic.

Surprisingly, item 20 - Malaysians feel that it is important to speak Arabic received no endorsement $(0 \%)$. What this means is that the students do not think that the ability to speak Arabic was valued by Malaysians at all. The respondents, perhaps reacted the way they did as they were studying to be English teachers. Due to this, they do not think the society puts as high value on Arabic as they do on English. However, this finding is in direct contradiction to the findings from Ibrahim and Rahman (2018) who believe that Malaysians value the language more nowadays from the growing interest in learning Arabic for religious as well as trade and diplomacy purposes. This also contradicts with current global trend towards the language. It has been shown that American society is more positive towards Arabic especially after September 11, 2001 tragedy. In fact, according to the Modern Language Association, demands for Arabic courses in American universities has increased by three folds (Goldberg et al., 2015). Presently, according to Heldt (2014) Arabic has become one of the fastest-growing foreign languages in the U.S.

Table-3. Students' beliefs about the nature of language learning (in \%).

\begin{tabular}{l|l|c|c|c}
\hline No & Statement & Disagree & Neutral & Agree \\
\hline 8. & $\begin{array}{l}\text { It is important to know about the foreign language - } \\
\text { speaking cultures in order to speak Arabic. }\end{array}$ & 12 & 41 \\
\hline 12. & It is best to learn Arabic in Arabic-speaking country. & 29 & 12 & 59 \\
\hline 17. & $\begin{array}{l}\text { The most important part of learning a foreign language is } \\
\text { learning vocabulary words. }\end{array}$ & 0 & 6 & 94 \\
\hline 23. & $\begin{array}{l}\text { The most important part of learning a foreign language is } \\
\text { learning the grammar. }\end{array}$ & 0 & 24 & 76 \\
\hline 27. & $\begin{array}{l}\text { Learning a foreign language is different than learning } \\
\text { other academic subjects. }\end{array}$ & 24 & \multirow{2}{*}{59} \\
\hline 28. & $\begin{array}{l}\text { The most important part of learning Arabic is learning } \\
\text { how to translate from my native language to Arabic or } \\
\text { from Arabic to my native language. }\end{array}$ & 12 & 64 \\
\hline Source: Horwitz (1987).
\end{tabular}

The third component in BALLI deals with beliefs about the nature of language learning. The results are presented in Table 3. Based on the result, students believe that learning vocabulary and grammar were highly important, at $94 \%$ and $74 \%$ respectively.

Table-4. Students' beliefs about difficulty of language learning (in \%).

\begin{tabular}{|c|c|c|c|c|}
\hline No & Statement & Disagree & Neutral & Agree \\
\hline 3. & Some languages are easier to learn than others. & 18 & 29 & 53 \\
\hline 4.* & Arabic is ... language & 41 & 47 & 12 \\
\hline $15 . *$ & $\begin{array}{l}\text { If someone spent one hour a day learning a } \\
\text { language, it will take them ..... years to speak } \\
\text { the language very well }\end{array}$ & 71 & 24 & 6 \\
\hline 25. & $\begin{array}{l}\text { It is easier to speak than understand a foreign } \\
\text { language. }\end{array}$ & 35 & 41 & 24 \\
\hline 34. & $\begin{array}{l}\text { It is easier to read and write this language than } \\
\text { to speak and understand it. }\end{array}$ & 6 & 18 & 76 \\
\hline
\end{tabular}

Note: *different ratings were used. 
Another belief, pertaining to the use of translation in learning also received high agreement (64\%). This shows that students have certain ideas with regard to ways to approach the language. The results are in agreement with Altan (2006). When students held this kind of beliefs, they will focus on learning grammar rules, vocabulary, and translating text. This method of learning is often associated with Grammar Translation Method, a popular approach in Malaysian schools when studying languages such as Arabic and English.

Table 4 presents results for beliefs on difficulty of language learning. Majority of Arabic learners (53\%) agree that some languages are easier than others. At the same time, for item 4, perceived difficulty of the foreign language they were enrolled, only a small percentage (12\%) think that Arabic is difficult, while a large majority of them (88\%) believes that it ranges from easy to average. These results support the notion of language learning difficulty hierarchy. Response to item 15 pertaining to duration needed to master a language, a great majority (71\%) think it can be done within 2 years. Based on these 2 responses, it clearly indicates that they believe Arabic is not very difficult thus it can be mastered within a short time. The results do not concur with previous studies (Horwitz, 1988) whereby students think the languages they learn are rather challenging.

Table-5. Students' beliefs about language learning and communicative strategies (in \%).

\begin{tabular}{|c|c|c|c|c|}
\hline No & Statement & Disagree & Neutral & Agree \\
\hline 7. & It is important to speak Arabic with an excellent pronunciation. & $\mathrm{O}$ & 18 & 82 \\
\hline 9. & You shouldn't say anything until you can say it correctly. & 53 & 41 & 6 \\
\hline 13. & I enjoy practicing Arabic with the native Arabic speakers I meet. & 35 & 35 & 30 \\
\hline 14. & It's o.k. to guess if you don't know a word in Arabic. & 29 & 6 & 65 \\
\hline 18. & It is important to repeat and practice a lot. & $\mathrm{O}$ & 6 & 94 \\
\hline 21. & I feel timid speaking Arabic with other people. & 41 & 35 & 24 \\
\hline 22. & $\begin{array}{l}\text { If beginning students are permitted to make errors, it will be } \\
\text { difficult for them to speak correctly later on. }\end{array}$ & 53 & 29 & 18 \\
\hline 26. & It is important to practice with cassettes or tapes. & 18 & 41 & 41 \\
\hline
\end{tabular}

Table 5 presents the results from the last component assessing beliefs about language learning and communicative strategies. The item that received highest agreement (94\%) in this category, stresses on the importance of repeating and practicing. Although the majority (82\%) agreed with the importance of having good pronunciation in Arabic, this belief did not stop them from disagreeing with item 9 rou shouldn't say anything until you can say it correctly as majority (53\%) disagreed with it. Similarly, item 14 It's o.k. to guess if you don't know a word in Arabic was endorsed by $65 \%$ of the students. These results contradict with M Hanan (2012 as cited in Rosni et al. (2016)) who found that student were reluctant to get involved in communicative activities.

\section{CONCLUSION AND RECOMMENDATION}

The purpose of the study was to explore the beliefs of TESL students about learning Arabic in UniSZA. Based on the findings, it can be concluded that students tend to have varied set of beliefs which are both realistic and unrealistic. Beliefs that are realistic such as willingness to speak and practice tend to facilitate learning process. Meanwhile, despite being familiar with the Arabic language in daily lives, students still hold unrealistic beliefs about it. This includes the belief that Arabic is not valued in our country which will impede the mastery of the language This is based on findings by Ghaith and Diab (2008) who found environment directly influences students' performance in using the language. Compared to previous studies on Arabic (Kuntz, 1996; Meshkat and Saeb, 2014) there are more similarities than differences in the findings. Therefore, in order to be successful in acquiring Arabic, students must be made aware of the difference between these two categories of beliefs. As Arabic is a useful language for religious and economic reasons, there is a need for more encouragement to be provided. One of the things that teachers can do is to try to persuade students to change their mindset regarding language learning. 


\section{IMPLICATIONS}

Despite being a small-scaled study, the study has made some pedagogical contributions to both language teachers and learners. Some of the beliefs are found to be unrealistic, which are harmful to their learning. Being able to identify what these beliefs are, is important for both teachers and students. Teachers must ensure students change the beliefs by highlighting them in class.

Another implication as Al-Mansour (2017) suggests is that Arabic language teachers should be able to straighten things out regarding negative ideas about Arabs. They should encourage students to view differences in the culture in a more positive rather than negative manner. Similarly, students must also do their share in changing their wrong perspectives pertaining to learning Arabic.

Funding: This study received no specific financial support.

Competing Interests: The authors declare that they have no competing interests.

Acknowledgement: Both authors contributed equally to the conception and design of the study.

\section{REFERENCES}

Al-Mansour, N.S., 2017. Effect of attitude on foreign language acquisition: Arabic pronunciation as case study. Arab World English Journal, 7(1): 310-325.

Altan, M.X., 2006. Beliefs about language learning of foreign language-major university students. Australian Journal of Teacher Education, $31(2)$ : 45-51.Available at: https://doi.org/10.14221/ajte.2006v31n2.5.

Ariogul, S., D.C. Unal and I. Onursal, 2009. Foreign language learners' beliefs about language learning: A study on Turkish university students. Procedia-Social and Behavioral Sciences, 1(1): 1500-1506.Available at: https://doi.org/10.1016/j.sbspro.2009.01.265.

$\begin{array}{llllll}\text { Department } & \text { of } & \text { Statistics } & \text { Malaysia, } & 2019 . & \text { Available }\end{array}$
https://www.dosm.gov.my/v1/index.php?r=column/ctheme\&menu_id=LopheU43NWJwRWVSZklWdzQ4TlhUUT 09\&bul_id=MDMxdHZjWTk1SjFzTzNkRXYzcVZjdzo9.

Gardner, R.C., 1985. Social psychology and second language learning: The role of attitudes and motivation. London: Edward Arnold.

Ghaith, G. and H. Diab, 2008. Determinants of EFL achievement among Arab college-bound learners. Education, Business and Society: Contemporary Middle Eastern Issues, 1(4): 278-286.Available at: https://doi.org/10.1108/17537980810929993.

Goldberg, D., D. Looney and N. Lusin, 2015. Enrollments in languages other than English in United States institutions of higher education, Fall 2013. (PDF). Modern Language Association. Available from https://apps.mla.org/pdf/2013_enrollment_survey.pdf.

Heldt, D., 2014. Arabic is fastest-growing language at U.S. colleges. The Gazette.

Horwitz, E.K., 1987. Surveying student beliefs about languagelearning.In A. Wenden \& J. Rubin (Eds.), Learningstrategies in language learning. Englewood Cliffs NY: Prentice Hall.

Horwitz, E.K., 1988. The beliefs about language learning of beginning university foreign language students. The Modern Language Journal, 72(3): 283-294.Available at: https://doi.org/10.1111/j.1540-4781.1988.tb04190.x.

Ibrahim, M.H. and A.K.A. Rahman, 2018. Teaching of Arabic in Malaysia. Intellectual Discourse, 26(1): 189-206.

Kuntz, P., 1996. Students of Arabic: Beliefs about foreign language learning. Al-'Arabiyya, 29: 153-176.

Marzano, R.J., 1992. Different kind of classroom: Teaching with dimensions of learning. (Report no. 0-87120-192-5). Alexandria, VA. The Association for Supervision and Curriculum Development. (ERIC Document Reproduction Service No. ED350086).

Meshkat, M. and F. Saeb, 2014. High-school students' beliefs about learning English and Arabic. International Journal of Applied Linguistics and English Literature, 3(3): 211-216.Available at: https://doi.org/10.7575/aiac.ijalel.v.3n.3p.211. 
Ministry of Higher Education Malaysia, 2007. National higher education strategic plan beyond 2020.

Rosni, b.S., F. Puteh-Behak, N.S.M. Saad, S.M. Ali, R. Darmi and H. Harun, 2016. Effective methods in learning Arabic language as a foreign language. Mediterranean Journal of Social Sciences, 7(3): 349-355.

Yusri, G., N. Rahimi, P.M. Shah and W. Wan Haslina, 2012. Attitude towards learning oral Arabic as a foreign language among Malaysian students. Pertanika Journal of Social Sciences \& Humanities, 2O(3): 765-779.

Views and opinions expressed in this article are the views and opinions of the author(s), International Journal of Asian Social Science shall not be responsible or answerable for any loss, damage or liability etc. caused in relation to/arising out of the use of the content. 